\title{
Beyond thrombosis: the impact of tissue factor signaling in cancer
}

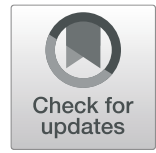

\author{
Dusten Unruh ${ }^{1 *}$ (D) and Craig Horbinski ${ }^{1,2}$
}

\begin{abstract}
Tissue factor (TF) is the primary initiator of the coagulation cascade, though its effects extend well beyond hemostasis. When TF binds to Factor VII, the resulting TF:FVlla complex can proteolytically cleave transmembrane G protein-coupled proteaseactivated receptors (PARs). In addition to activating PARs, TF:FVlla complex can also activate receptor tyrosine kinases (RTKs) and integrins. These signaling pathways are utilized by tumors to increase cell proliferation, angiogenesis, metastasis, and cancer stem-like cell maintenance. Herein, we review in detail the regulation of TF expression, mechanisms of TF signaling, their pathological consequences, and how it is being targeted in experimental cancer therapeutics.
\end{abstract}

Keywords: Tissue factor, Protease-activated receptors, Receptor tyrosine kinases, Integrins, Metastasis, Angiogenesis

\section{Introduction}

Tissue factor (TF), also named Factor III, CD142, or thromboplastin, is a transmembrane glycoprotein that participates in the rate-limiting step of the coagulation cascade. It derives its name from the ability of tissue extracts from platelets, leukocytes, and organs to clot blood. Morawitz is credited with developing the "classical" theory of blood coagulation in 1905, wherein prothrombin is converted into thrombin when incubated with tissue extracts and calcium [1]. He postulated that components for blood clotting are always present in circulating blood, except for TF (then named thrombokinase), which must be released from tissues [2]. Thirty years later, Howell used the term "Tissue Factor" to describe an extract from tissues that promotes coagulation [3]. TF is constitutively expressed in the subendothelial spaces and adventitia, where it acts as a hemostatic envelope to halt bleeding when it encounters calcium and coagulation factors. TF is abundantly expressed in highly vascularized organs, like the brain, lungs, placenta, heart, and kidneys $[4,5]$. During vascular injury, TF is exposed

\footnotetext{
* Correspondence: dusten.unruh@northwestern.edu

'Department of Neurological Surgery, Northwestern University, 303 East Superior St, Chicago, IL 60611, USA

Full list of author information is available at the end of the article
}

to the blood, where it functions as a cofactor for the circulating zymogen factor VII (FVII). This TF:FVIIa complex can then bind and activate either factor IX (FIX) or factor $\mathrm{X}(\mathrm{FX})$, triggering a cascade that generates fibrin and activates platelets, resulting in a hemostatic plug at the site of injury.

TF is highly expressed in many types of cancer [6], and cancer cells can shed TF-active microvesicles (TFMVs) into the circulation [7]. Not surprisingly, many cancers cause venous thromboembolism (VTE), with high levels of flTF-MVs correlating with increased VTE risk [8]. As a group, cancer patients have an $\sim 6$-fold increased risk of VTE compared to the general population [9-11]. This paraneoplastic event is called "Trousseau Syndrome," named after the French physician Armand Trousseau, who was among the first to describe this in the 19th century in his cancer patients [12]. (He also developed VTE himself in 1867 and correctly diagnosed himself with fatal gastric cancer.)

It is now clear, however, that TF has other major roles beyond hemostasis and thrombosis. Ancient organisms like the horseshoe crab (Limulus polyphemus) use proteins similar to TF as an immune response to entrap pathogens [13]. Indeed, many components of the mammalian coagulation system share similarities with 
inflammatory molecules of the immune system, and that, in addition to coagulation, they play important roles in immunity and wound healing [13]. Cancers can use these TF-activated pathways to enhance cell proliferation, cell survival, angiogenesis, metastasis, and cancer stem-like cell (CSC) maintenance. In fact, because of these similarities to wound healing, cancer has been called "the wound that does not heal" [14].

Herein, we present a general overview of the mechanisms controlling TF expression in cancer, discuss TFmediated signaling pathways, highlight how TF controls cancer progression, and review TF-targeted therapeutic strategies being tested to improve cancer management.

\section{TF structure and isoforms}

TF is encoded by $F 3$, a $12.5 \mathrm{~kb}$ gene located on chromosome $1 \mathrm{p} 21.3$. This gene contains 6 exons that can produce two different proteins. One protein, the product of all 6 exons, is full-length TF (flTF). The other is an alternatively spliced isoform, termed asTF (Fig. 1). These two proteins have an apparent molecular mass of $\sim 47 \mathrm{kDa}$ and $\sim 26 \mathrm{kDa}$, respectively, after sodium dodecyl sulfatepolyacrylamide gel electrophoresis (SDS-PAGE) $[15,16]$.

Human flTF is a 263 amino acid transmembrane glycoprotein that is comprised of an extracellular domain (residues 1-219), a transmembrane domain (residues 220-242), and an intracellular C-terminal domain (residues 243-263). This portion of TF is structurally homologous to class II cytokine receptors $[17,18]$. The extracellular portion of flTF contains two fibronectin type III domains and two disulfide bridges at $\mathrm{Cys}^{49}$ $\mathrm{Cys}^{57}$ and $\mathrm{Cys}^{186}-\mathrm{Cys}^{209}[19]$. Although the extracellular domain of TF is structurally similar to the class II cytokine receptors, it does not bind to any cytokines. Instead, it binds to coagulation factor VII (FVII) zymogen. The cytoplasmic C-terminal domain of flTF does not contain any significant homology with other proteins, and it lacks adaptor motifs usually found in the cytokine receptor superfamily that bind with Janus kinase-signal transducer and activator of transcription (JAK-STAT) effectors. Instead, TF's cytoplasmic C-terminal domain interacts with a variety of scaffolding and adapter proteins that influence cytoskeletal structure and cell signaling.

In 2003, Bogdanov et al. first described asTF, in which exon 5 is spliced out and exons 4 and 6 are fused together. This causes a shift in the open reading frame that produces a unique 40 amino acid C-terminus [15]. The unique C-terminus of asTF lacks a transmembrane domain and is secreted. Although asTF retains a Lys ${ }^{165}$ and

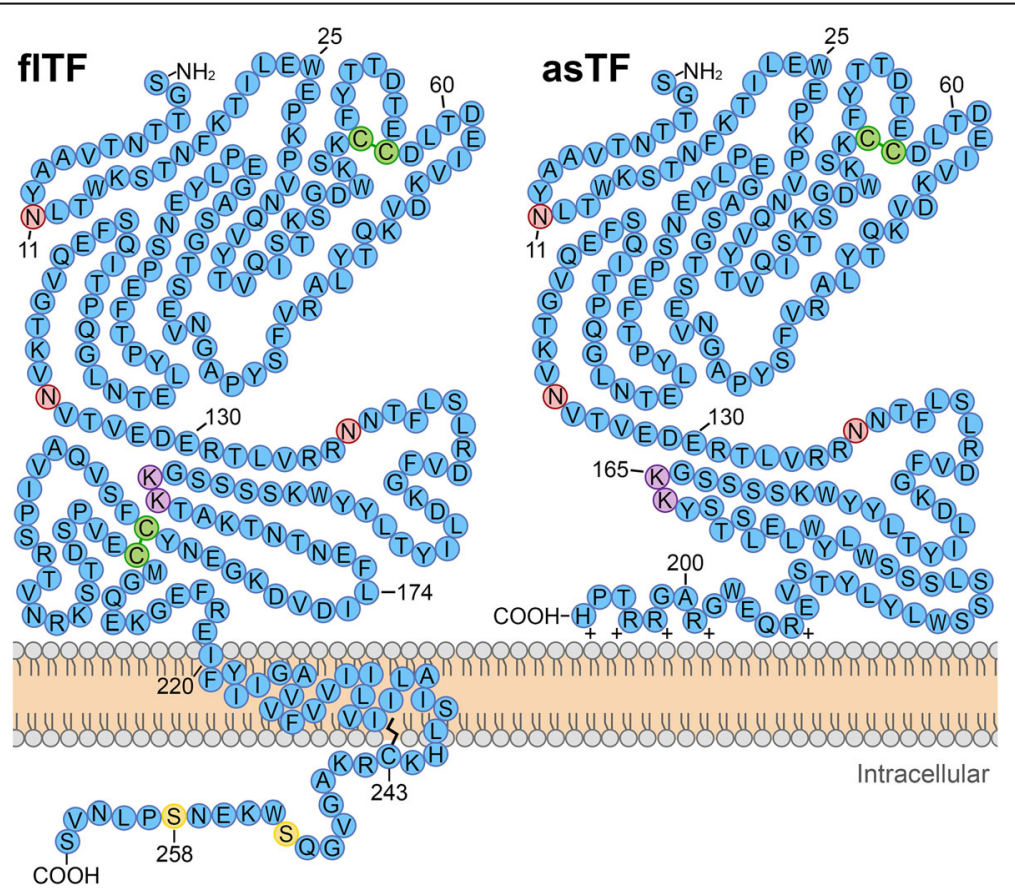

Fig. 1 Full length TF (fITF) and alternatively spliced TF (asTF) primary protein structure. fITF is an integral transmembrane protein, whereas asTF lacks a transmembrane and can be secreted. Both isoforms contain the same first 166 residues, which share an N-terminal $\beta$-sandwich and the charged lysine doublet (purple circles) necessary for FVII/FVIla binding. Disulfide bridges are shown with green circles. Glycosylation has been reported to occur on asparagine at sites N11, N124, and N137 (red circles). fITF contains two serine residues in the C-terminus that can undergo phosphorylation (yellow circles). Palmitoylation of C243 is thought to orientate fITF in the plasma membrane. Through alternative splicing of the gene that encodes for TF, F3, a frame shift occurs and generates a unique C-terminus, resulting in the formation of asTF. asTF's unique C-terminus contains a cluster of five positively charged residues $(+)$ that allow asTF to interact with cell membranes 
Lys ${ }^{166}$ doublet, which is required for TF:FVIIa complex formation, its procoagulant activity is questionable, as it lacks a complete binding site for coagulation factors IX and $X$ [15]. Indeed, asTF has minimal to no procoagulant activity when compared to flTF in vitro [20-22]. However, these studies were primarily conducted in flTF deficient conditions, and asTF may indirectly trigger coagulation [23, 24]. Even so, Ünlü et al. observed that asTF does not affect receptor-ligand kinetics of flTF on endothelial cells [21]. Because of asTF's positively charged C-terminus, it likely requires a negatively charged phospholipid membrane to promote coagulation, which is often found in cancer.

In addition to alternative splicing, $\mathrm{TF}$ can undergo post-translational modifications. The extracellular domain has three $\mathrm{N}$-linked glycosylation sites $\left(\mathrm{Asn}^{11}\right.$, $\mathrm{Asn}^{124}$, and $\mathrm{Asn}^{137}$ ), and TF glycosylation may affect the charge of TF and its affinity to FVII [25, 26]. It has widely been assumed that recombinant TF and naturally occurring TF are identical, but Krudysz-Amblo et al. showed that TF derived from the placenta was 5-fold more procoagulant than recombinant $\mathrm{TF}$ and that this difference was due to increased glycosylation of placental TF [27]. Phosphorylation is another post-translational modification that affects TF signaling, discussed below. The C-terminus of TF contains two phosphorylation sites $\left(\mathrm{Ser}^{253}\right.$ and $\mathrm{Ser}^{258}$ ) [28]. TF can also undergo palmitoylation, the covalent attachment of fatty acid palmitate to a cysteine (S-palmitoylation) or, less frequently, to threonine or serine (O-palmitoylation) [29]. Palmitoylation controls a wide variety of cellular functions, including protein subcellular trafficking, protein stability, and protein-protein interactions [29]. The intracellular domain of TF has one S-palmitoylation site $\left(\mathrm{Cys}^{245}\right)$ [30], which suppresses phosphorylation of $\mathrm{Ser}^{258}$ in the TF Cterminus [31]. However, the extent of TF palmitoylation, and whether it influences plasma membrane microdomain trafficking, is still unclear.

\section{Noncoagulant signaling by tissue factor}

Although TF is classified as a cytokine class II receptor, its signaling mechanism differs greatly from that family of receptors. TF can trigger both proteolytic and non-proteolytic cell signaling, and both TF isoforms have unique mechanisms of action (Fig. 2). On tumor cells, flTF binds the inactive zymogen, FVII, forming a flTF:FVII complex in which FVII is rapidly converted into an active protease, FVIIa. The flTF: FVIIa complex then binds and activates FX, creating a ternary flTF:FVIIa:FXa complex. This complex cleaves several protease-activated receptors (PARs), which belong to the seven-transmembrane G proteincoupled receptor family whose members are irreversibly activated by proteolytic cleavage of the $\mathrm{N}$ - terminus. Cleavage of the N-terminus on PAR releases its tethered ligand, allowing it to fold back on itself and bind to the extracellular portion of loop 2, in turn altering the binding affinity of PAR to intracellular heterotrimeric $G$ proteins. These $G$ proteins are composed of three unique subunits, $\alpha, \beta$, and $\gamma$, and act as molecular switches inside cells to initiate a remarkably diverse array of functions.

To date, the PAR group of receptors consists of PAR1, PAR2, PAR3, and PAR4. TF activation of the coagulation cascade generates thrombin, and PAR1 was first discovered in 1991 as a receptor for thrombin on platelets [32]. PAR1, PAR3, and PAR4 are all activated by thrombin; PAR2 is the only PAR that is not [33]. The flTF: FVIIa:FXa complex can directly cleave both PAR1 and PAR2, and flTF:FVIIa can cleave PAR2. Signaling by the flTF:FVIIa:FXa complex is supported by the endothelial protein $\mathrm{C}$ receptor (EPCR), enabling PAR signaling, and is required for the induction of proinflammatory genes [34, 35]. In contrast, flTF:FVIIa elicits MAPK signaling through PAR2, not PAR1, and also promotes calcium mobilization, activation of Src family kinases, and activation of other pathways like PI3K, JAK/STAT, and $\beta$ catenin [36-43]. However, studies show that PARs often exist in close proximity to each another and are capable of forming homodimers and heterodimers [44]. Furthermore, cleaved PAR2 can transactivate PAR1, and vice versa [44, 45]. Thus, both PAR1 and PAR2 signaling are closely linked, and can potentially lead to each other's activation by proxy.

Once PARs are cleaved, they can transactivate nearby membrane-bound receptor tyrosine kinases (RTKs) [46]. Such transactivation could occur via one of two mechanisms: (i) ligand-independent recruitment of nontyrosine kinases; (ii) a "triple membrane passing signal" mechanism wherein membrane-bound matrix metalloproteases are activated, leading to receptor ligand shedding, in turn causing paracrine and/or autocrine RTK activation [47]. flTF:FVIIa cleavage of PARs causes transactivation of multiple RTKs, including EGFR, PDGFR $\beta$, and IGF-1R [48-51]. Because this generally happens within minutes, and does not depend on secreted ligand, flTF:FVIIa transactivation of RTKs through PARs is mostly via the former, ligandindependent mechanism. In fact, flTF:FVIIa activation of PAR2 leads to RTK phosphorylation via a ligandindependent, Src-dependent intracellular pathway [4851]. This means that even when extracellular ligands for RTKs are absent or when cells are in the presence of extracellular RTK inhibitors, flTF:FVIIa may still activate those RTKs through PAR2. Even though intracellular activation of RTKs via flTF may confer resistance to RTK small molecule inhibitors, anti-RTK antibodies are often still clinically effective [52]. 


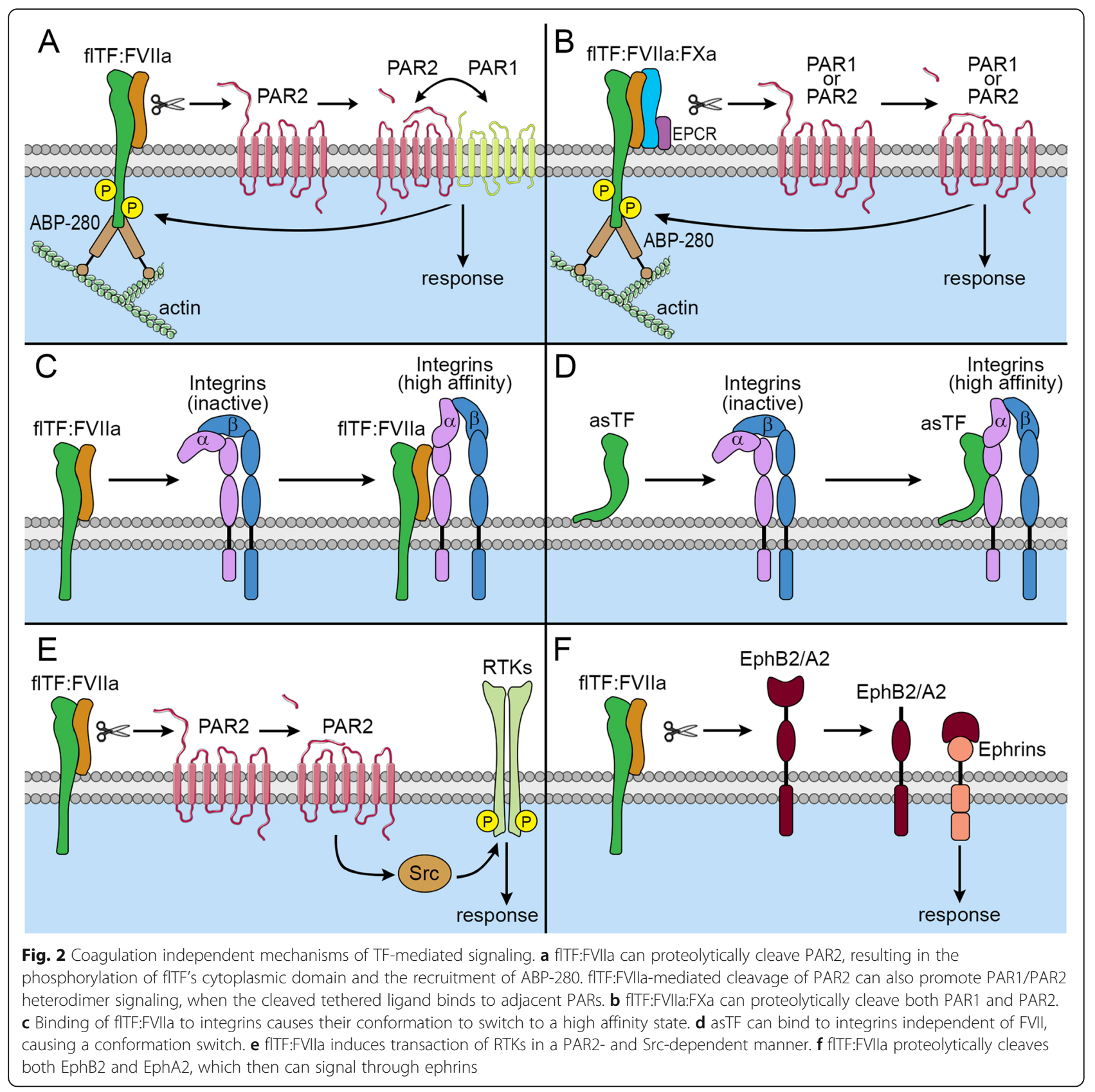

A lot of TF's non-coagulant effects are dependent on integrins. These are heterodimeric transmembrane receptors that function as adhesion molecules for both cell-cell and cell-extracellular matrix (ECM) interactions, and mediate a variety of biological processes that include survival, proliferation, stemness, and migration [53]. There are 24 integrins, each being composed of various combinations of $\alpha$ and $\beta$ subunits. Integrins can assume three conformation states, including bent (inactive), extended (intermediate affinity), or extended with open conformation (high affinity) [54]. flTF directly interacts with $\alpha 3, \alpha 6$, and $\beta 1$ integrin subunits $[55,56]$, and flTF:
FVIIa associates with $\beta 1$ subunits in the active conformation, thus inducing the internalization of the TF:FVIIa$\beta 1$ integrin complex via GTPase Arf6 [57]. Although PAR2 activation enhances the affinity of flTF:FVIIa to $\beta 1$ integrins, blocking PAR2 activation is not sufficient to prevent flTF:FVIIa binding to $\beta 1$ integrins [56].

In addition to flTF:FVIIa cleaving PAR2, it also cleaves receptors in the Eph RTK family [58]. The Eph RTK family includes 14 members separated into nine EphA and five EphB receptors, that govern cell proliferation, differentiation, and mobility [59, 60]. flTF:FVIIa directly cleaves both EphB2 and EphA2, independent of PAR2 
activation or the flTF:FVIIa:FXa ternary complex [58]. The consequences of this are the subject of ongoing investigation.

The flTF cytoplasmic domain plays an especially important role in non-coagulant signaling. It serves as a scaffold for molecules involved in adhesion, migration, and cytoskeleton organization, such as actin-binding protein-280 (ABP-280). TF localizes to lamellipodia, which are created by cytoskeletal protein actin projections on the invasive edges of cells [61-63]. TF binding of ABP-280 may also positively regulate its release via flTF-MVs [64], resulting in paracrine signaling [65]. The flTF cytoplasmic domain is phosphorylated at Ser253 by protein kinase $\mathrm{C}$ (PKC) and at Ser258 by p38 MAPK $[28,31,36,66]$. Such phosphorylation promotes the physical association of flTF with $\alpha 3 \beta 1$ integrins, thereby enhancing cell migration on laminin 5 [55]. This flTF cytoplasmic domain interacts with the PI3K regulatory subunit p55 and is required for flTF-induced interleukin-8 (IL-8) expression and resultant angiogenesis [57]. The cytoplasmic domain of flTF does not affect the procoagulant activity of flTF, nor does it alter the proteolytic activation of PAR2 by flTF:FVIIa [57, 67-69]. However, once the flTF cytoplasmic domain is phosphorylated, it inhibits PAR2-dependent angiogenesis [55, 70]. Interestingly, mice lacking the flTF cytoplasmic domain do not die in utero, unlike TF-deficient mice, and flTF:FVIIa association with $\beta 1$-integrin does not require the cytoplasmic domain $[57,71]$.

Whereas flTF can either remain anchored within the cell membrane or be secreted, asTF lacks the transmembrane domain and is only secreted. Although asTF is not very pro-coagulant, it does have non-hemostatic functions. For example, asTF is a powerful pro-angiogenic molecule via non-proteolytic ligation of both $\alpha 6 \beta 1$ and $\alpha V \beta 3$ integrins, leading to increased FAK, PI3K/AKT, and MAPK signaling [16, 72]. In contrast to flTF, asTF can bind integrins without the help of FVII [16].

\section{Regulation of tissue factor expression}

TF is constitutively expressed on a wide variety of cells, especially in the perivascular niche, where it surrounds the abluminal side of the blood vessel, ensuring that clot formation happens quickly once blood escapes the endothelium [4, 73]. Endothelial cells that are normally in contact with blood express very little TF at baseline, though certain stimuli can trigger its upregulation, like bacterial lipopolysaccharide [74, 75]. Several miRNAs, including miR-181b, miR-19, miR-20a, miR-93/106b, and miR-520 g, can bind to the $F 3$ transcript and limit its translation into TF [76-80]. PARP-14 is another posttranscriptional regulator of TF expression that reduces TF RNA levels by forming a complex with the mRNA-destabilizing protein tristetraprolin [81].
Multiple growth factors and cytokines induce TF expression. For example, hepatocyte growth factor (HGF) upregulates TF by activating Met in a Src kinasedependent manner [82]. Other growth factors, including basic fibroblast growth factor (bFGF), platelet-derived growth factor (PDGF)-BB, PDGF-CC, PDGF-AA, bone morphogenetic protein-7 (BMP-7), transforming growth factor- $\beta$ (TGF- $\beta$ ), and vascular endothelial growth factor (VEGF) can also increase TF [83-90]. During inflammation, TF can be upregulated by a variety of cytokines and signaling molecules, including interferon- $\gamma$ (IFN- $\gamma$ ), tumor necrosis factor- $\alpha$ (TNF- $\alpha)$, IL-6, IL-1 $\beta$, IL-33, and histamine [91-99]. Activated $\mathrm{T}$ lymphocytes release CD40-ligand (CD40L), which also induces TF [100]. Conversely, the anti-inflammatory cytokines IL-4, IL-10, and IL-13 all suppress TF [101-103].

In cancer, TF expression can be directly driven by prooncogenic events (Fig. 3). For example, mutations in the tumor suppressor TP53 and proto-oncogene KRAS activate MAPK and PI3K/AKT signaling pathways, in turn stimulating TF expression [104, 105]. In glioma, amplification of epidermal growth factor receptor (EGFR) and/ or its constitutively active mutant form, EGFRvIII, promotes the expression of TF, PARs, and ectopic synthesis of FVII, thus sensitizing the cells to TF-mediated signaling [106]. EGFR-mediated TF expression depends on activator protein-1 (AP-1) and is associated with c-Jun $\mathrm{NH}(2)$-terminal kinase (JNK) and JunD activation [107]. Blocking EGFR signaling in human carcinoma and glioma cells diminishes TF expression [108]. Loss of the tumor suppressor Pten or E-cadherin also leads to TF upregulation [109-111]. In neuroblastoma, MYCN amplification positively correlates with TF [112].

Cancer-associated hypoxia also stimulates TF expression via canonical hypoxia-associated signaling molecules, including hypoxia-inducible factor 1-alpha, early growth response gene-1 (Egr-1), Cyr61, and VEGF [113, $114]$. In glioblastoma (GBM), hypoxia is sufficient to increase TF production in cultured GBM cells, and tumor cells surrounding necrotic, hypoxic zones stain strongly for TF $[109,115]$.

In contrast, we found that gliomas with mutations in isocitrate dehydrogenase 1 or IDH2 (collectively "IDH ${ }^{\text {mut") }}$ hypermethylate the early coding region of $F 3$ and suppress its transcription, correlating with less flTFMV production, less risk of VTE, and less aggressive behavior $[116,117]$. This appears to be unique to $\operatorname{IDH}^{\text {mut }}$ gliomas, as other IDH ${ }^{\text {mut }}$ cancers, like cholangiocarcinoma and acute myeloid leukemia, neither hypermethylate F3 nor suppress TF production $[51,116]$.

\section{Pathophysiological effects of TF signaling}

While TF clearly has critical roles to play in normal hemostatic and non-hemostatic cell functions, such 


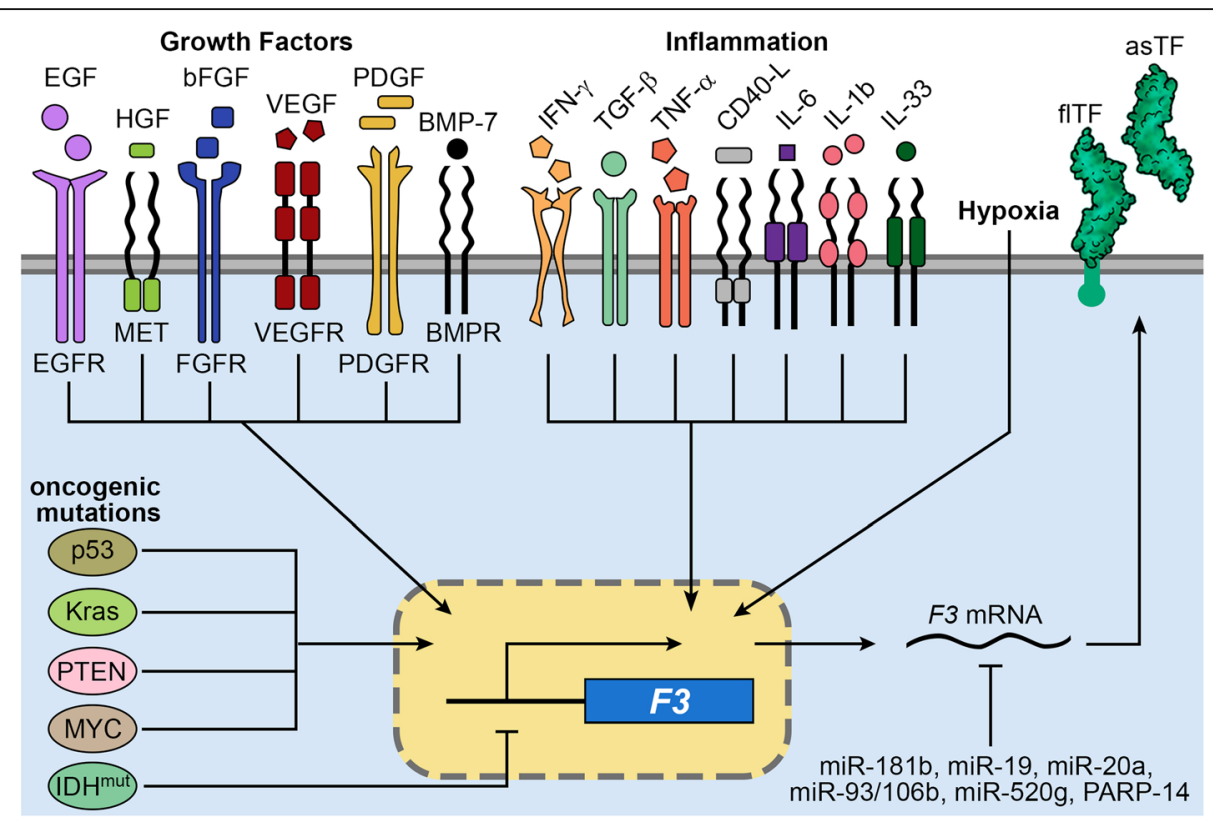

Fig. 3 Induction of tissue factor expression in cancer. Growth factors, inflammation, hypoxia, and oncogenic signaling mechanisms activate signaling pathways that drive the expression of TF. Conversely, TF is downregulated by some micro RNAs (miRs), and by hypermethylation induced by IDH ${ }^{\text {mut }}$

activities can also greatly contribute to the malignant behavior of cancer. Elevated TF is a common feature of many cancers, and generally correlates with worse patient survival (Fig. 4) [6]. Here, we will discuss some of the key studies examining the pathological consequences of TF expression in cancer, including effects on angiogenesis, invasion, cell survival, metastasis, and maintenance of cancer stem-like cell (CSC) populations.

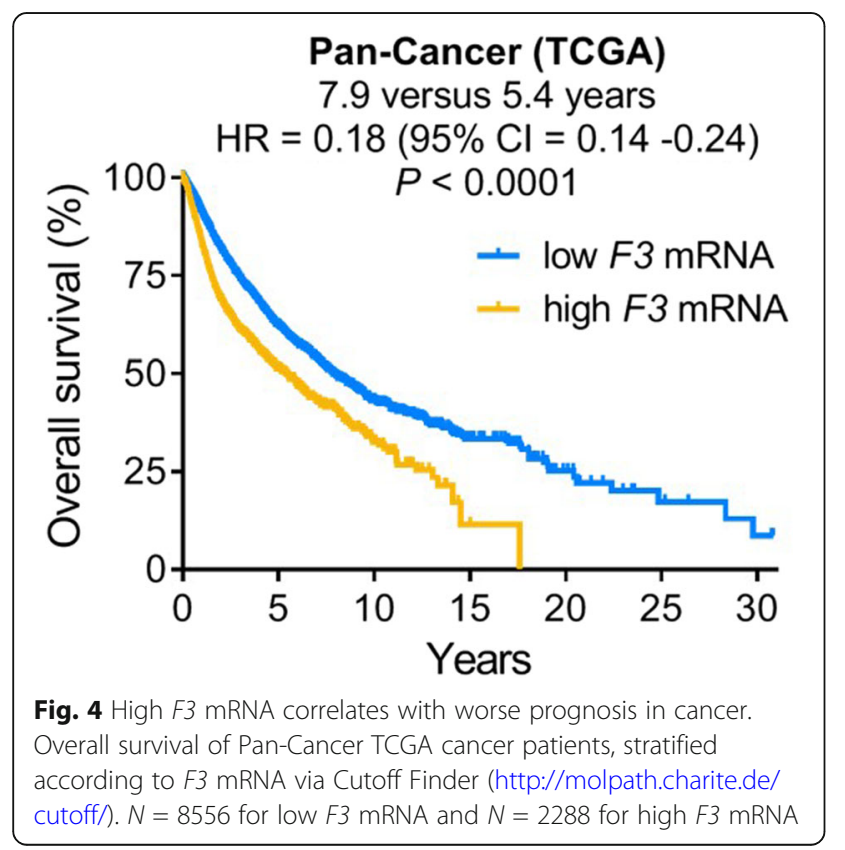

\section{Tumor angiogenesis}

flTF:FVIIa activation of PAR2 triggers downstream transcription of several proangiogenic genes, including VEGF, IL8, FGF2, and CXCL1 [38, 118-120]. The cytoplasmic domain of flTF is important for controlling VEGF expression, and its phosphorylation correlates with VEGF expression in cancer [121-123]. Consistent with this, flTF deletion results in vascular failure during embryogenesis, and just deleting the flTF cytoplasmic domain is sufficient to suppress VEGF production [121, $122,124]$. Of note, although flTF deletion in mice results in vascular abnormalities, it does not phenocopy VEGF deletion [125]. Positive correlations between flTF and vascular density have been reported in cancers of the brain, pancreas, prostate, large bowel, lung, and breast [126-131]. This seems to be primarily through PAR2, because although some have also implicated PAR1 in blood vessel growth, PAR1-deficient mice show normal wound healing and postnatal angiogenesis [132-135]. Studies in PAR1- and PAR2-deficient mice further support the notion that signaling through PAR2, but not PAR1, is important for tumor angiogenesis [136].

Like flTF, elevated expression of asTF increases the expression of multiple genes that promote angiogenesis like VEGF, AREG, and EFEMP1 [23], and at least part of asTF-induced cancer angiogenesis is dependent on ligation of $\beta 1$ and $\beta 3$ integrins [16, 137]. Furthermore, asTF does not require FVIIa to induce angiogenesis [16]. High expression of asTF correlates with worse patient survival in lung and gastric cancer [138, 139]. 


\section{Proliferation, cell survival, and apoptosis}

Both flTF and asTF can increase the proliferation of many different kinds of cancer, though perhaps by different mechanisms [140]. In colon cancer cells, flTF: FVIIa activates PAR2, leading to increased proliferation through the PKC $\alpha$ and ERK1/2 pathways [141, 142]. In breast cancer cells, the pro-proliferative effect of asTF depends on $\beta 1$ integrin [143]. However, the response of cancers to TF likely depends on their molecular background. For example, we found that GBM cells with driver mutations in EGFR are far more dependent on endogenous TF for cell proliferation than GBM cells with driver mutations in NF1 [116].

flTF has a number of anti-apoptotic effects in cancer cells, including activation of PI3K, AKT, and JAK/ STAT5 signaling pathways; suppression of deathassociated protein kinase-1; and upregulation of $\mathrm{Bcl}_{\mathrm{XL}}$ [144-148]. As a result, flTF can prevent anoikis (Greek for "homeless"), a form of apoptosis that is induced by the lack of anchorage-dependent survival signaling caused by loss of surrounding extracellular matrix [143, $146,149]$.

\section{Cancer stem-like cells}

Special subpopulations of cells within cancer are capable of self-renewal. These cells are commonly referred to as cancer stem-like cells (CSCs), and they contribute to therapy resistance, recurrence, and distal metastasis [150]. Our data, and that of others, indicate that TF contributes to the CSC phenotype [151]. For example, TF is positively correlated with well-known markers of CSC like CD44 and CD133, and is enriched on CSCs compared to cancer cells without self-renewing capacity [152-156]. In conditional knock-down experiments, lack of TF can prevent the growth of some xenografted cancers for prolonged periods of time, followed by abrupt and rapid growth when TF expression is restored [157]. Conversely, others found that TF may not be a regulator of CSC populations in all cancer types. Schaffner et al. showed that EPCR negative cells and receptor blocking EPCR antibodies reduced breast cancer stem cell populations, whereas TF expression did not alter the CSC phenotype [158].

\section{Invasion and metastasis}

Metastasis is a Greek word meaning "displacement" and is the result of multiple cellular processes working together to allow cancer cells to invade normal tissue beyond the original tumor site, survive while traveling through the blood or lymphatic system, and form a new tumor in a distant site. TF is prominently expressed at the invasive edge of tumors and positively correlates with invasiveness in cancers from a variety of organs, including the liver, breast, pancreas, and lung [159-162].
TF expression is also up to 1000 -fold greater in metastatic cells than in non-metastatic cells [163]. An unbiased shRNA screen showed that TF is one of the most powerful drivers of metastasis in osteosarcoma [164]. Such correlative findings have been verified by functional studies in vivo $[23,163,165]$.

The mechanisms underpinning TF's effects on invasion and metastasis mostly resemble those already noted in other pro-malignant functions. The pro-invasive effects of flTF on cancer cells appear to depend on the cytoplasmic domain, as expression of mutant flTF constructs that lack the cytoplasmic domain are far less metastatic $[166,167]$. The cytoplasmic domain of flTF promotes invasion by activating the GTPase Rac1 and p38 MAPK, which interact with actin filaments and cause extension of filopodia and lamellipodia [61]. flTFmediated activation of PAR2 also recruits actin-binding protein to the cytoplasmic domain of flTF, and promotes cytoskeleton reorganization and cell motility by activating MAPK and cofilin pathways [62, 63, 168]. Activated PAR2 stabilizes and increases $\beta$-catenin expression [169], and in glioma, the pro-invasive effects of flTF: FVIIa is dependent in part on $\beta$-catenin [116]. However, flTF- $\beta 1$ integrin interaction promotes cell migration when the flTF cytoplasmic domain is phosphorylated [55], suggesting the requirement of PAR2 activation. In contrast, asTF can increase cell motility by directly binding and activating $\beta 1$ integrins [170].

The release of flTF-MVs by tumors can also promote metastasis via paracrine signaling within the tumor microenvironment and at distal sites. flTF-MVs are elevated in the plasma of cancer patients [171, 172] and can activate PAR1 and PAR2 on nonmalignant cells [173, 174]. Endothelial cells that are stimulated with flTF-MVs express increased adhesion molecules and secrete pro-inflammatory molecules that can recruit protumor monocytes, establishing a pre-metastatic niche for circulating cancer cells $[173,175]$.

In addition to the aforementioned suppression of anoikis, flTF-mediated activation of the coagulation pathway is important once cancer cells enter the bloodstream. Two monoclonal inhibitory antibodies were developed to study the role of blood coagulation in metastasis. The first, mAb-10H10, blocks flTF:FVIIa-mediated PAR2 activation without any significant effect on coagulation. The second, mAb-5G9, blocks the formation of the flTF: FVIIa:FXa complex, thereby inhibiting stimulation of both PAR1 and PAR2, as well as impairing coagulation [176]. Using both antibodies in a model of patientderived breast cancer xenografts, Versteeg et al. showed that, whereas mAb-10H10 inhibited primary tumor growth, mAb-5G9 inhibited its metastatic spread [56]. Palumbo et al. suggested that flTF further supports tumor metastasis via thrombin-dependent and platelet- 
dependent mechanisms that prevent natural killer cell clearance of cancer cells [177]. In sum, both TFmediated thrombin generation and TF-mediated intracellular signaling contribute to distal metastasis.

\section{Tissue factor as a target for cancer therapy}

Because TF plays multiple roles in the malignant behavior of cancer, blocking its signaling might improve cancer treatment. A direct inhibitor of TF:FVIIa, recombinant nematode anticoagulant protein c2 (rNAPc2), has been shown to reduce tumor growth in preclinical models of colorectal cancer and melanoma [178, 179]. These findings promoted a clinical trial to test the safety of rNAPc2 to treat colon cancer (ClinicalTrial.gov, ID NCT00443573); however, this study was suspended, and no results were published. rNAPc2 has a narrow therapeutic window, with a high risk of bleeding complications [180], and this could likely explain why the rNAPc2 trial was suspended. Although directly targeting TF disrupts normal hemostasis and increases risk of uncontrollable hemorrhage, there are ways of blocking non-hemostatic aspects of TF activity. For example, the clinical grade formulation of the mAb-10H10 (CNTO 2559) does not interfere with hemostasis and has inhibited breast cancer growth in mice [181].

As discussed above, one of the primary targets of flTF is the PAR signaling nexus. Because flTF activates PARs independently of its role in coagulation, targeting PARs could limit many of the pro-cancer effects of flTF without the dangerous side effects of direct flTF inhibition. Small molecule PAR inhibitors have therefore been tested as potential cancer therapeutics. The PAR2 antagonist, GB88, and its derivatives, block PAR2 activation and reduced inflammation, yet these inhibitors have low $\mathrm{IC}_{50}$ and solubility, limiting their effectiveness in vivo [182-184]. Furthermore, for unclear reasons, GB88 blocks only certain PAR2-mediated signaling pathways, such as $\mathrm{Ca}^{2+}$ mobilization, but not MAPK signaling [185]. Recently, a new PAR2 antagonist, I-191, was developed that has a much higher $\mathrm{IC}_{50}$ and solubility and blocks both $\mathrm{Ca}^{2+}$ mobilization and MAPK signaling [182]. Two PAR1 inhibitors exist, atopaxar and vorapaxar, and both inhibit cancer progression in preclinical models [186]. An additional approach for blocking PAR signaling involves the use of cell-penetrating peptide antagonists termed "pepducins" [187]. PAR1targeting pepducin P1pal-7 blocked lung cancer cell migration and inhibited lung tumor growth by $75 \%$ [188]. For excellent in-depth reviews on targeting PARs, see Ramachandran et al. and Hamilton et al. $[185,189]$. However, while PAR inhibitors seem to be well-tolerated in animal models, it remains to be determined whether targeting PAR1 or PAR2 will prove effective in cancer patients.
flTF requires FVII and FX complex formation for efficient proteolytic signaling. Because FVII and FX are vitamin K-dependent, their expression can be reduced by using vitamin $\mathrm{K}$ antagonists, like warfarin, which has been shown to suppress tumorigenesis [190-192]. Warfarin also blocks the growth and spread of pancreatic cancer by inhibiting signaling of another RTK, Axl [193]. An FXa inhibitor, rivaroxaban, did not directly affect the growth of TF-positive pancreatic cancer xenografts in immunodeficient mice [194], but did suppress tumor growth in an immunocompetent setting that was partially dependent on reprograming tumor-associated macrophages [195]. A selective small molecule inhibitor of FVIIa, PCI-27483, inhibited tumor growth in preclinical models [196], although combining it with gemcitabine was not clearly superior to gemcitabine alone in a phase 2 clinical trial against pancreatic cancer [197].

Because TF is highly expressed on the surface of many kinds of cancer cells, some have investigated the ability of TF-specific antibody:drug conjugates to deliver tumoricidal drugs. One prominent example is a human anti-TF antibody conjugated to the cytotoxic agent monomethyl auristatin E (TF-011-MMAE) [198]. TF011-MMAE has suppressed tumor growth and metastasis in a variety of preclinical cancer models, even those expressing relatively low amounts of TF, without significant effect on coagulation, and showed better intracellular internalization than antibody:drug conjugates targeting EGFR or HER2 [198-200]. TF-011-MMAE, now renamed HuMax-TF-ADC, has undergone multiple phase 1 trials demonstrating its safety and is currently undergoing a multicenter phase 2 clinical trial for safety and efficacy against cervical cancer and solid tumors (ClinicalTrial.gov, ID: NCT03438396, NCT03485209).

$\mathrm{Hu}$ et al. have developed chimeric antibody-like homodimers that consist of FVII fused to the Fc domain of IgG1 [201]. These immunoconjugates, which are named "ICONs," target TF-expressing tumors, and induce both antibodydependent cellular cytotoxicity and complement-dependent cytotoxicity [202-204]. ICONs lack procoagulant activity due to the elimination of $\mathrm{Lys}^{341}$, and when administered intravenously, inhibit the growth of melanoma, prostate, and head and neck tumors [201, 202, 205]. Because first generation ICONs are relatively large molecules $(210 \mathrm{kDa})$, their bioavailability within solid tumors is questionable. A smaller $(100 \mathrm{kDa})$, more efficient second-generation ICON, LICON1, is now being evaluated in preclinical studies [206].

A rapidly emerging immunotherapy strategy for treating cancer is chimeric antigen receptor (CAR)-modified $\mathrm{T}$ cells (CAR T) $[207,208]$. To date, CAR T therapy against hematopoietic cancers has met with some success [209], but whether it has real potential against solid tumors is debatable. One limiting factor of CAR $\mathrm{T}$ in solid tumors is finding suitable antigens to target [207, 
208]. Zhang et al. developed human $\mathrm{T}$ cells modified to express the light chain of mouse FVII, since it binds strongly to both human and mouse TF [210]. These cells, termed TF-CAR $\mathrm{T}$ cells, reduced tumor growth and metastasis in NOG mice with human lung cancer xenografts [210]. However, off-target toxicity is one of the main limiting factors of CAR T therapy, so although the authors found no toxicity in mice from the TF-CAR $\mathrm{T}$ cells [210], it still remains to be determined whether this approach will have any off-target toxicity in humans.

Since the secreted TF isoform, asTF, also plays a prominent role in cancer malignancy but is only minimally procoagulant, it can be directly targeted without worrying about bleeding. Bogdanov et al. developed an asTF-specific neutralizing antibody termed "RabMab1" $[15,143,170]$. RabMab1 is capable of blocking asTF from binding to integrins and inhibits pancreatic and breast cancer growth in vivo $[143,170]$. Other than RabMab1, asTF-specific therapies are scarce. However, other asTF-directed approaches could potentially include inhibitory RNAs that specifically target the unique exons 4-6 spliced sequence or by blocking splicing regulatory proteins that produce asTF [211].

\section{Conclusion and future perspectives}

It is now clear that TF has a wide range of activities beyond thrombosis, and that these activities are utilized by cancers to increase their malignancy. Further insights into TF signaling, and how to block pro-cancer effects while retaining its hemostatic capacity, may lead to more effective therapies against the pro-tumor effects of TF.

\begin{abstract}
Abbreviations
asTF: Alternatively spliced tissue factor; bFGF: Basic fibroblast growth factor; BMP: Bone morphogenetic protein; CAR T: Chimeric antigen receptormodified T cells; FVII: Coagulation factor VII; FIX: Coagulation factor IX; FX: Coagulation factor X; CSC: Cancer stem-like cells; EGFR: Epidermal growth factor receptor; EPCR: Endothelial protein C receptor; fITF: Full-length tissue factor; GBM: Glioblastoma; HGF: Hepatocyte growth factor;

ICONs: Immunoconjugates; INF- $\gamma$ : Interferon- $\gamma$; MVs: Microvesicles; rNAPC2: Nematode anticoagulant protein C2; PAR: Protease-activated receptor; PKC: Protein kinase C; PDGF: Platelet-derived growth factor; RTKs: Receptor tyrosine kinases; TF: Tissue factor; TGF- $\beta$ : Transforming growth factor- $\beta$; TNF-a: Tumor necrosis factor-a; VEGF: Vascular endothelial growth factor; VTE: Venous thromboembolism
\end{abstract}

\section{Acknowledgements}

None

\section{Authors' contributions}

D.U. and C.H. conceptualized and wrote the manuscript. D.U. created the figures. All authors read and approved the final manuscript.

\section{Funding}

D.U. was supported by the grant F32CA216996 from the National Institutes of Health (NIH). C.H. was supported by NIH grants R01NS102669, R01NS117104, the Northwestern University SPORE in Brain Cancer P50CA221747, and the Lou and Jean Malnati Brain Tumor Institute.
Availability of data and materials

Not applicable for this review

\section{Competing interest}

The authors declare no competing interests.

Ethics approval and consent to participate

Not applicable for this review

Consent for publication

Not applicable for this review

\section{Author details}

${ }^{1}$ Department of Neurological Surgery, Northwestern University, 303 East Superior St, Chicago, IL 60611, USA. ²Department of Pathology, Northwestern University, Chicago, IL 60611, USA.

Received: 1 June 2020 Accepted: 2 July 2020

Published online: 14 July 2020

\section{References}

1. Morawitz P. Die Chemie der Blutgerinnung. Ergebnisse der Physiologie. 1905;4(1):307-422

2. Boulton F. A hundred years of cascading - started by Paul Morawitz (18791936), a pioneer of haemostasis and of transfusion. Transfus Med. 2006; 16(1):1-10.

3. Bächli M. Esther. Historical review. British Journal of Haematology. 2000; 110(2):248-55

4. Drake TA, Morrissey JH, Edgington TS. Selective cellular expression of tissue factor in human tissues. Implications for disorders of hemostasis and thrombosis. The American journal of pathology. 1989;134(5):1087-97.

5. Osterud B, Bjorklid E. Sources of tissue factor. Seminars in thrombosis and hemostasis. 2006:32(1):11-23.

6. van den Berg YW, Osanto S, Reitsma PH, Versteeg HH. The relationship between tissue factor and cancer progression: insights from bench and bedside. Blood. 2012;119(4):924-32.

7. Owens AP 3rd, Mackman N. Microparticles in hemostasis and thrombosis. Circulation research. 2011;108(10):1284-97.

8. Hisada Y, Mackman N. Cancer-associated pathways and biomarkers of venous thrombosis. Blood. 2017;130(13):1499-506.

9. Falanga A. Thrombophilia in cancer. Seminars in thrombosis and hemostasis. 2005:31(1):104-10.

10. Heit JA, O'Fallon WM, Petterson TM, Lohse CM, Silverstein MD, Mohr DN, et al. Relative impact of risk factors for deep vein thrombosis and pulmonary embolism: a population-based study. Arch Intern Med. 2002; 162(11):1245-8.

11. Rickles FR. Mechanisms of cancer-induced thrombosis in cancer. Pathophysiol Haemost Thromb. 2006:35(1-2):103-10.

12. Varki A. Trousseau's syndrome: multiple definitions and multiple mechanisms. Blood. 2007;110(6):1723-9.

13. Delvaeye $\mathrm{M}$, Conway EM. Coagulation and innate immune responses: can we view them separately? Blood. 2009:114(12):2367-74.

14. Dvorak HF. Tumors: wounds that do not heal. Similarities between tumor stroma generation and wound healing. N Engl J Med. 1986;315(26):1650-9.

15. Bogdanov $\mathrm{Y}$, , Balasubramanian $\mathrm{V}$, Hathcock J, Vele O, Lieb M, Nemerson Y. Alternatively spliced human tissue factor: a circulating, soluble, thrombogenic protein. Nature medicine. 2003:9(4):458-62.

16. van den Berg YW, van den Hengel LG, Myers HR, Ayachi O, Jordanova E, Ruf W, et al. Alternatively spliced tissue factor induces angiogenesis through integrin ligation. Proc Natl Acad Sci U S A. 2009;106(46):19497-502.

17. Muller YA, Ultsch MH, de Vos AM. The crystal structure of the extracellular domain of human tissue factor refined to 1.7 A resolution. J Mol Biol. 1996; 256(1):144-59.

18. Camerer $\mathrm{E}$, Kolsto $\mathrm{AB}$, Prydz H. Cell biology of tissue factor, the principal initiator of blood coagulation. Thrombosis research. 1996;81(1):1-41

19. Pendurthi UR, Ghosh S, Mandal SK, Rao LV. Tissue factor activation: is disulfide bond switching a regulatory mechanism? Blood. 2007;110(12): 3900-8.

20. Censarek P, Bobbe A, Grandoch M, Schror K, Weber AA. Alternatively spliced human tissue factor (asHTF) is not pro-coagulant. Thrombosis and haemostasis. 2007;97(1):11-4. 
21. Unlu B, Bogdanov VY, Versteeg HH. Interplay between alternatively spliced tissue factor and full length tissue factor in modulating coagulant activity of endothelial cells. Thrombosis research. 2017;156:1-7.

22. Boing AN, Hau CM, Sturk A, Nieuwland R. Human alternatively spliced tissue factor is not secreted and does not trigger coagulation. J Thromb Haemost. 2009;7(8):1423-6.

23. Unruh D, Turner K, Srinivasan R, Kocaturk B, Qi X, Chu Z, et al. Alternatively spliced tissue factor contributes to tumor spread and activation of coagulation in pancreatic ductal adenocarcinoma. International journal of cancer. 2014;134(1):9-20.

24. Unruh D, Sagin F, Adam M, Van Dreden P, Woodhams BJ, Hart K, et al. Levels of alternatively spliced tissue factor in the plasma of patients with pancreatic cancer may help predict aggressive tumor phenotype. Annals of surgical oncology. 2015;22(Suppl 3):S1206-11.

25. Paborsky LR, Harris RJ. Post-translational modifications of recombinant human tissue factor. Thrombosis research. 1990;60(5):367-76.

26. Stone MJ, Ruf W, Miles DJ, Edgington TS, Wright PE. Recombinant soluble human tissue factor secreted by Saccharomyces cerevisiae and refolded from Escherichia coli inclusion bodies: glycosylation of mutants, activity and physical characterization. Biochem J. 1995;310(Pt 2):605-14.

27. Krudysz-Amblo J, Jennings ME 2nd, Mann KG, Butenas S. Carbohydrates and activity of natural and recombinant tissue factor. The Journal of biological chemistry. 2010;285(5):3371-82

28. Zioncheck TF, Roy S, Vehar GA. The cytoplasmic domain of tissue factor is phosphorylated by a protein kinase C-dependent mechanism. The Journal of biological chemistry. 1992;267(6):3561-4.

29. Linder ME, Deschenes RJ. Palmitoylation: policing protein stability and traffic. Nat Rev Mol Cell Biol. 2007;8(1):74-84

30. Bach $\mathrm{R}$, Konigsberg $\mathrm{WH}$, Nemerson $\mathrm{Y}$. Human tissue factor contains thioester-linked palmitate and stearate on the cytoplasmic half-cystine. Biochemistry. 1988;27(12):4227-31.

31. Dorfleutner A, Ruf W. Regulation of tissue factor cytoplasmic domain phosphorylation by palmitoylation. Blood. 2003;102(12):3998-4005.

32. Vu TK, Wheaton VI, Hung DT, Charo I, Coughlin SR. Domains specifying thrombin-receptor interaction. Nature. 1991;353(6345):674-7.

33. Heuberger DM, Schuepbach RA. Protease-activated receptors (PARs): mechanisms of action and potential therapeutic modulators in PAR-driven inflammatory diseases. Thromb J. 2019;17:4.

34. Disse J, Petersen HH, Larsen KS, Persson E, Esmon N, Esmon CT, et al. The endothelial protein $\mathrm{C}$ receptor supports tissue factor ternary coagulation initiation complex signaling through protease-activated receptors. The Journal of biological chemistry. 2011;286(7):5756-67.

35. Liang HP, Kerschen EJ, Hernandez I, Basu S, Zogg M, Botros F, et al. EPCRdependent PAR2 activation by the blood coagulation initiation complex regulates LPS-triggered interferon responses in mice. Blood. 2015;125(18): 2845-54.

36. Ahamed J, Ruf W. Protease-activated receptor 2-dependent phosphorylation of the tissue factor cytoplasmic domain. The Journal of biological chemistry. 2004:279(22):23038-44

37. Fan L, Yotov W, Zhu T, Esmailzadeh L, Joyal JS, Sennlaub F, et al. Tissue factor enhances protease-activated receptor-2-mediated factor Vlla cell proliferative properties. J Thromb Haemost. 2005;3(5):1056-63.

38. Hjortoe GM, Petersen LC, Albrektsen T, Sorensen BB, Norby PL, Mandal SK, et al. Tissue factor-factor Vlla-specific up-regulation of IL-8 expression in MDA-MB-231 cells is mediated by PAR-2 and results in increased cell migration. Blood. 2004;103(8):3029-37.

39. Camerer E, Rottingen JA, Gjernes E, Larsen K, Skartlien AH, Iversen JG, et al. Coagulation factors VIla and Xa induce cell signaling leading to up-regulation of the egr-1 gene. The Journal of biological chemistry. 1999;274(45):32225-33.

40. Taubman MB, Marmur JD, Rosenfield CL, Guha A, Nichtberger S, Nemerson Y. Agonist-mediated tissue factor expression in cultured vascular smooth muscle cells. Role of $\mathrm{Ca} 2+$ mobilization and protein kinase $\mathrm{C}$ activation. The Journal of clinical investigation. 1993;91(2):547-52.

41. Fang J, Gu L, Zhu N, Tang H, Alvarado CS, Zhou M. Tissue factor/FVlla activates $\mathrm{BCl}-2$ and prevents doxorubicin-induced apoptosis in neuroblastoma cells. BMC cancer. 2008;8:69.

42. Versteeg HH, Sorensen BB, Slofstra SH, Van den Brande JH, Stam JC. van Bergen en Henegouwen PM, et al. Vlla/tissue factor interaction results in a tissue factor cytoplasmic domain-independent activation of protein synthesis, p70, and p90 S6 kinase phosphorylation. The Journal of biological chemistry. 2002;277(30):27065-72.
43. Versteeg HH, Hoedemaeker I, Diks SH, Stam JC, Spaargaren M. van Bergen En Henegouwen PM, et al. Factor Vlla/tissue factor-induced signaling via activation of Src-like kinases, phosphatidylinositol 3-kinase, and Rac. The Journal of biological chemistry. 2000;275(37):28750-6.

44. Lin H, Liu AP, Smith TH, Trejo J. Cofactoring and dimerization of proteinaseactivated receptors. Pharmacol Rev. 2013:65(4):1198-213.

45. Sevigny LM, Austin KM, Zhang P, Kasuda S, Koukos G, Sharifi S, et al. Protease-activated receptor-2 modulates protease-activated receptor-1driven neointimal hyperplasia. Arteriosclerosis, thrombosis, and vascular biology. 2011;31(12):e100-6.

46. Daub H, Weiss FU, Wallasch C, Ullrich A. Role of transactivation of the EGF receptor in signalling by G-protein-coupled receptors. Nature. 1996; 379(6565):557-60.

47. Wang Z. Transactivation of epidermal growth factor receptor by $\mathrm{G}$ proteincoupled receptors: recent progress, challenges and future research. International journal of molecular sciences. 2016;17(1).

48. Wiiger MT, Prydz H. The epidermal growth factor receptor (EGFR) and proline rich tyrosine kinase 2 (PYK2) are involved in tissue factor dependent factor Vlla signalling in HaCaT cells. Thrombosis and haemostasis. 2004;92(1): 13-22.

49. Siegbahn A, Johnell M, Nordin A, Aberg M, Velling T. TF/FVlla transactivate PDGFRbeta to regulate PDGF-BB-induced chemotaxis in different cell types: involvement of Src and PLC. Arteriosclerosis, thrombosis, and vascular biology. 2008;28(1):135-41.

50. Aberg M, Eriksson O, Mokhtari D, Siegbahn A. Tissue factor/factor Vlla induces cell survival and gene transcription by transactivation of the insulin-like growth factor 1 receptor. Thrombosis and haemostasis. 2014;111(4):748-60.

51. Unruh D, Zewde M, Buss A, Drumm MR, Tran AN, Scholtens DM, et al. Methylation and transcription patterns are distinct in IDH mutant gliomas compared to other IDH mutant cancers. Scientific reports. 2019:9(1):8946.

52. Shabani M, Hojjat-Farsangi M. Targeting receptor tyrosine kinases using monoclonal antibodies: the most specific tools for targeted-based cancer therapy. Curr Drug Targets. 2016;17(14):1687-703.

53. Cooper J, Giancotti FG. Integrin signaling in cancer: mechanotransduction, stemness, epithelial plasticity, and therapeutic resistance. Cancer cell. 2019; 35(3):347-67.

54. Askari JA, Buckley PA, Mould AP, Humphries MJ. Linking integrin conformation to function. Journal of cell science. 2009;122(Pt 2):165-70.

55. Dorfleutner A, Hintermann E, Tarui T, Takada Y, Ruf W. Cross-talk of integrin alpha3beta1 and tissue factor in cell migration. Molecular biology of the cell. 2004;15(10):4416-25.

56. Versteeg $H H$, Schaffner $F$, Kerver $M$, Petersen $H H$, Ahamed J, FeldingHabermann B, et al. Inhibition of tissue factor signaling suppresses tumor growth. Blood. 2008;111(1):190-199.

57. Rothmeier AS, Liu E, Chakrabarty S, Disse J, Mueller BM, Ostergaard H, et al. Identification of the integrin-binding site on coagulation factor Vlla required for proangiogenic PAR2 signaling. Blood. 2018;131(6):674-85.

58. Eriksson O, Ramstrom M, Hornaeus K, Bergquist J, Mokhtari D, Siegbahn A. The Eph tyrosine kinase receptors EphB2 and EphA2 are novel proteolytic substrates of tissue factor/coagulation factor Vlla. The Journal of biological chemistry. 2014;289(47):32379-91.

59. Lisabeth EM, Falivelli G, Pasquale EB. Eph receptor signaling and ephrins. Cold Spring Harb Perspect Biol. 2013;5(9).

60. Liang LY, Patel O, Janes PW, Murphy JM, Lucet IS. Eph receptor signalling: from catalytic to non-catalytic functions. Oncogene. 2019;38(39):6567-84.

61. Ott I, Weigand B, Michl R, Seitz I, Sabbari-Erfani N, Neumann FJ, et al. Tissue factor cytoplasmic domain stimulates migration by activation of the GTPase Rac1 and the mitogen-activated protein kinase p38. Circulation. 2005;111(3):349-55.

62. Ott I, Fischer EG, Miyagi Y, Mueller BM, Ruf W. A role for tissue factor in cell adhesion and migration mediated by interaction with actin-binding protein 280. J Cell Biol. 1998;140(5):1241-53.

63. Muller M, Albrecht S, Golfert F, Hofer A, Funk RH, Magdolen V, et al. Localization of tissue factor in actin-filament-rich membrane areas of epithelial cells. Exp Cell Res. 1999:248(1):136-47.

64. Koizume S, Ito S, Yoshioka Y, Kanayama T, Nakamura Y, Yoshihara M, et al. High-level secretion of tissue factor-rich extracellular vesicles from ovarian cancer cells mediated by filamin-A and protease-activated receptors. Thrombosis and haemostasis. 2016;115(2):299-310.

65. Bogdanov W, Versteeg HH. "Soluble Tissue Factor" in the 21st century: definitions, biochemistry, and pathophysiological role in thrombus formation. Seminars in thrombosis and hemostasis. 2015;41(7):700-7. 
66. Ettelaie C, Elkeeb AM, Maraveyas A, Collier ME. p38alpha phosphorylates serine 258 within the cytoplasmic domain of tissue factor and prevents its incorporation into cell-derived microparticles. Biochim Biophys Acta. 2013; 1833(3):613-21.

67. Mueller BM, Ruf W. Requirement for binding of catalytically active factor VIla in tissue factor-dependent experimental metastasis. The Journal of clinical investigation. 1998;101(7):1372-8.

68. Wolberg AS, Kon RH, Monroe DM, Ezban M, Roberts HR, Hoffman M. Deencryption of cellular tissue factor is independent of its cytoplasmic domain. Biochemical and biophysical research communications. 2000;272(2):332-6.

69. Carson SD, Bromberg ME. Tissue factor encryption/de-encryption is not altered in the absence of the cytoplasmic domain. Thrombosis and haemostasis. 2000;84(4):657-63.

70. Belting M, Dorrell Ml, Sandgren S, Aguilar E, Ahamed J, Dorfleutner A, et al. Regulation of angiogenesis by tissue factor cytoplasmic domain signaling. Nature medicine. 2004;10(5):502-9.

71. Melis E, Moons L, De Mol M, Herbert JM, Mackman N, Collen D, et al. Targeted deletion of the cytosolic domain of tissue factor in mice does not affect development. Biochemical and biophysical research communications. 2001;286(3):580-6.

72. Hobbs JE, Zakarija A, Cundiff DL, Doll JA, Hymen E, Cornwell M, et al. Alternatively spliced human tissue factor promotes tumor growth and angiogenesis in a pancreatic cancer tumor model. Thrombosis research. 2007;120(Suppl 2):S13-21.

73. Fleck RA, Rao LV, Rapaport SI, Varki N. Localization of human tissue factor antigen by immunostaining with monospecific, polyclonal anti-human tissue factor antibody. Thrombosis research. 1990;59(2):421-37.

74. Eisenreich A, Rauch U. Regulation and differential role of the tissue factor isoforms in cardiovascular biology. Trends Cardiovasc Med. 2010;20(6):199-203.

75. Mészáros K, Aberle S, Dedrick R, Machovich R, Horwitz A, Birr C, et al. Monocyte tissue factor induction by lipopolysaccharide (LPS): dependence on LPSbinding protein and CD14, and inhibition by a recombinant fragment of bactericidal/permeability-increasing protein. Blood. 1994;83(9):2516-25.

76. Witkowski M, Witkowski M, Saffarzadeh M, Friebel J, Tabaraie T, Ta Bao L, et al. Vascular miR-181b controls tissue factor-dependent thrombogenicity and inflammation in type 2 diabetes. Cardiovasc Diabetol. 2020;19(1):20.

77. Zhang X, Yu H, Lou JR, Zheng J, Zhu H, Popescu NI, et al. MicroRNA-19 (miR-19) regulates tissue factor expression in breast cancer cells. The Journal of biological chemistry. 2011;286(2):1429-35.

78. Balia C, Giordano M, Scalise V, Neri T, Fontanini G, Basolo F, et al. miR-19a and miR-20a and tissue factor expression in activated human peripheral blood mononuclear cells. Thrombosis. 2017;2017:1076397.

79. Chuang TD, Luo X, Panda H, Chegini N. miR-93/106b and their host gene, MCM7, are differentially expressed in leiomyomas and functionally target F3 and IL-8. Mol Endocrinol. 2012;26(6):1028-42.

80. D'Asti E, Huang A, Kool M, Meehan B, Chan JA, Jabado N, et al. Tissue factor regulation by miR-520 $\mathrm{g}$ in primitive neuronal brain tumor cells: a possible link between oncomirs and the vascular tumor microenvironment. The American journal of pathology. 2016;186(2):446-59.

81. Iqbal MB, Johns M, Cao J, Liu Y, Yu SC, Hyde GD, et al. PARP-14 combines with tristetraprolin in the selective posttranscriptional control of macrophage tissue factor expression. Blood. 2014;124(24):3646-55.

82. Provencal M, Labbe D, Veitch R, Boivin D, Rivard GE, Sartelet H, et al. c-Met activation in medulloblastoma induces tissue factor expression and activity: effects on cell migration. Carcinogenesis. 2009:30(7):1089-96.

83. Corseaux D, Meurice T, Six I, Rugeri L, Ezekowitz MD, Rouvier P, et al. Basic fibroblast growth factor increases tissue factor expression in circulating monocytes and in vascular wall. Circulation. 2000;101(16):2000-6.

84. Kamimura M, Bea F, Akizawa T, Katus HA, Kreuzer J, Viedt C. Platelet-derived growth factor induces tissue factor expression in vascular smooth muscle cells via activation of Egr-1. Hypertension. 2004:44(6):944-51.

85. Gebhard C, Akhmedov A, Mocharla P, Angstenberger J, Sahbai S, Camici GG, et al. PDGF-CC induces tissue factor expression: role of PDGF receptor alpha/beta. Basic Res Cardiol. 2010;105(3):349-56.

86. Schecter AD, Giesen PL, Taby O, Rosenfield CL, Rossikhina M, Fyfe BS, et al. Tissue factor expression in human arterial smooth muscle cells. TF is present in three cellular pools after growth factor stimulation. The Journal of clinical investigation. 1997;100(9):2276-85.

87. Sovershaev TA, Egorina EM, Unruh D, Bogdanov W, Hansen JB, Sovershaev MA. BMP-7 induces TF expression in human monocytes by increasing F3 transcriptional activity. Thrombosis research. 2015;135(2):398-403.
88. Zucker S, Mirza H, Conner CE, Lorenz AF, Drews MH, Bahou WF, et al. Vascular endothelial growth factor induces tissue factor and matrix metalloproteinase production in endothelial cells: conversion of prothrombin to thrombin results in progelatinase A activation and cell proliferation. International journal of cancer. 1998;75(5):780-6.

89. Wygrecka M, Zakrzewicz D, Taborski B, Didiasova M, Kwapiszewska G, Preissner KT, et al. TGF-beta1 induces tissue factor expression in human lung fibroblasts in a PI3KJJNK Akt-dependent and AP-1-dependent manner. Am J Respir Cell Mol Biol. 2012;47(5):614-27.

90. Saito M, Ichikawa J, Ando T, Schoenecker JG, Ohba T, Koyama K, et al. Platelet-derived TGF-beta induces tissue factor expression via the Smad3 pathway in osteosarcoma cells. J Bone Miner Res. 2018;33(11):2048-58.

91. Witkowski M, Landmesser U, Rauch U. Tissue factor as a link between inflammation and coagulation. Trends Cardiovasc Med. 2016;26(4):297-303.

92. Osterud B, Unruh D, Olsen JO, Kirchhofer D, Owens AP 3rd, Bogdanov W. Procoagulant and proinflammatory effects of red blood cells on lipopolysaccharidestimulated monocytes. J Thromb Haemost. 2015;13(9):1676-82

93. Bastarache JA, Sebag SC, Grove BS, Ware LB. Interferon-gamma and tumor necrosis factor-alpha act synergistically to up-regulate tissue factor in alveolar epithelial cells. Exp Lung Res. 2011;37(8):509-17.

94. Eden D, Siegbahn A, Mokhtari D. Tissue factor/factor Vlla signalling promotes cytokine-induced beta cell death and impairs glucose-stimulated insulin secretion from human pancreatic islets. Diabetologia. 2015;58(11): 2563-72.

95. Steffel J, Akhmedov A, Greutert H, Luscher TF, Tanner FC. Histamine induces tissue factor expression: implications for acute coronary syndromes. Circulation. 2005;112(3):341-9.

96. Neumann FJ, Ott I, Marx N, Luther T, Kenngott S, Gawaz M, et al. Effect of human recombinant interleukin-6 and interleukin-8 on monocyte procoagulant activity. Arteriosclerosis, thrombosis, and vascular biology. 1997;17(12):3399-405.

97. Elsayed YA, Nakagawa K, Ichikawa K, Ohkawara S, Sueishi K. Expression of tissue factor and interleukin-1 beta in a novel rabbit model of disseminated intravascular coagulation induced by carrageenan and lipopolysaccharide. Pathobiology. 1995;63(6):328-40.

98. Puhlmann M, Weinreich DM, Farma JM, Carroll NM, Turner EM, Alexander $\mathrm{HR}$ Jr. Interleukin-1 beta induced vascular permeability is dependent on induction of endothelial tissue factor (TF) activity. J Transl Med. 2005;3:37.

99. Stojkovic S, Kaun C, Basilio J, Rauscher S, Hell L, Krychtiuk KA, et al. Tissue factor is induced by interleukin-33 in human endothelial cells: a new link between coagulation and inflammation. Scientific reports. 2016;6:25171.

100. Schonbeck U, Mach F, Sukhova GK, Herman M, Graber P, Kehry MR, et al. CD40 ligation induces tissue factor expression in human vascular smooth muscle cells. The American journal of pathology. 2000;156(1):7-14.

101. Kamimura M, Viedt C, Dalpke A, Rosenfeld ME, Mackman N, Cohen DM, et al. Interleukin-10 suppresses tissue factor expression in lipopolysaccharide-stimulated macrophages via inhibition of Egr-1 and a serum response element/MEK-ERK1/2 pathway. Circulation research. 2005; 97(4):305-13.

102. Toltl LJ, Beaudin S, Liaw PC. Activated protein C up-regulates IL-10 and inhibits tissue factor in blood monocytes. Journal of immunology (Baltimore, Md : 1950). 2008;181(3):2165-73.

103. Del Prete G, De Carli M, Lammel RM, D'Elios MM, Daniel KC, Giusti B, et al. Th1 and Th2 T-helper cells exert opposite regulatory effects on procoagulant activity and tissue factor production by human monocytes. Blood. 1995;86(1):250-7.

104. Yu JL, May L, Lhotak V, Shahrzad S, Shirasawa S, Weitz Jl, et al. Oncogenic events regulate tissue factor expression in colorectal cancer cells: implications for tumor progression and angiogenesis. Blood. 2005;105(4): 1734-41.

105. Rao B, Gao Y, Huang J, Gao X, Fu X, Huang M, et al. Mutations of p53 and K-ras correlate TF expression in human colorectal carcinomas: TF downregulation as a marker of poor prognosis. Int J Colorectal Dis. 2011; 26(5):593-601.

106. Magnus N, Garnier D, Rak J. Oncogenic epidermal growth factor receptor up-regulates multiple elements of the tissue factor signaling pathway in human glioma cells. Blood. 2010;116(5):815-8.

107. Rong Y, Belozerov VE, Tucker-Burden C, Chen G, Durden DL, Olson JJ, et al. Epidermal growth factor receptor and PTEN modulate tissue factor expression in glioblastoma through JunD/activator protein-1 transcriptional activity. Cancer research. 2009;69(6):2540-9. 
108. Milsom CC, Yu JL, Mackman N, Micallef J, Anderson GM, Guha A, et al. Tissue factor regulation by epidermal growth factor receptor and epithelialto-mesenchymal transitions: effect on tumor initiation and angiogenesis. Cancer research. 2008:68(24):10068-76.

109. Rong Y, Post DE, Pieper RO, Durden DL, Van Meir EG, Brat DJ. PTEN and hypoxia regulate tissue factor expression and plasma coagulation by glioblastoma. Cancer research. 2005;65(4):1406-13.

110. Fang J, Tang H, Xia LH, Wei WN, Hu Y, Song SJ. Regulation of tissue factor expression by anti-oncogene PTEN in human neuroblastoma cell line. Zhonghua Xue Ye Xue Za Zhi. 2007:28(6):363-6.

111. Regina S, Valentin JB, Lachot S, Lemarie E, Rollin J, Gruel Y. Increased tissue factor expression is associated with reduced survival in non-small cell lung cancer and with mutations of TP53 and PTEN. Clin Chem. 2009;55(10):183442.

112. Sherief LM, Hassan TH, Zakaria M, Fathy M, Eshak EA, Bebars MA, et al. Tissue factor expression predicts outcome in children with neuroblastoma: a retrospective study. Oncology letters. 2019;18(6):6347-54.

113. Sun L, Liu Y, Lin S, Shang J, Liu J, Li J, et al. Early growth response gene-1 and hypoxia-inducible factor-1alpha affect tumor metastasis via regulation of tissue factor. Acta Oncol. 2013;52(4):842-51.

114. Eisenreich A, Zakrzewicz A, Huber K, Thierbach H, Pepke W, Goldin-Lang P, et al. Regulation of pro-angiogenic tissue factor expression in hypoxiainduced human lung cancer cells. Oncology reports. 2013;30(1):462-70.

115. Monteiro RQ, Lima LG, Goncalves NP, MR DES, Leal AC, Demasi MA, et al. Hypoxia regulates the expression of tissue factor pathway signaling elements in a rat glioma model. Oncology letters. 2016;12(1):315-322.

116. Unruh D, Mirkov S, Wray B, Drumm M, Lamano J, Li YD, et al. Methylationdependent tissue factor suppression contributes to the reduced malignancy of IDH1 mutant gliomas. Clin Cancer Res. 2018.

117. Unruh D, Schwarze SR, Khoury L, Thomas C, Wu M, Chen L, et al. Mutant IDH1 and thrombosis in gliomas. Acta Neuropathol. 2016.

118. Liu Y, Mueller BM. Protease-activated receptor-2 regulates vascular endothelial growth factor expression in MDA-MB-231 cells via MAPK pathways. Biochemical and biophysical research communications. 2006; 344(4):1263-70.

119. Song HB, Park KD, Kim JH, Kim DH, Yu YS, Kim JH. Tissue factor regulates tumor angiogenesis of retinoblastoma via the extracellular signal-regulated kinase pathway. Oncology reports. 2012;28(6):2057-62.

120. Schaffner F, Versteeg HH, Schillert A, Yokota N, Petersen LC, Mueller BM, et al. Cooperation of tissue factor cytoplasmic domain and PAR2 signaling in breast cancer development. Blood. 2010;116(26):6106-13.

121. Abe K, Shoji M, Chen J, Bierhaus A, Danave I, Micko C, et al. Regulation of vascular endothelial growth factor production and angiogenesis by the cytoplasmic tail of tissue factor. Proc Natl Acad Sci U S A. 1999;96(15):8663-8.

122. Zhang J, Ding J, Zhang X, Shao X, Hao Z. Regulation of vascular endothelial growth factor (VEGF) production and angiogenesis by tissue Factor (TF) in SGC-7901 gastric cancer cells. Cancer biology \& therapy. 2005;4(7):769-72.

123. Ryden L, Grabau D, Schaffner F, Jonsson PE, Ruf W, Belting M. Evidence for tissue factor phosphorylation and its correlation with protease-activated receptor expression and the prognosis of primary breast cancer. International journal of cancer. 2010;126(10):2330-40.

124. Carmeliet P, Mackman N, Moons L, Luther T, Gressens P, Van Vlaenderen I, et al. Role of tissue factor in embryonic blood vessel development. Nature. 1996;383(6595):73-5.

125. Ho VC, Fong GH. Vasculogenesis and angiogenesis in VEGF receptor-1 deficient mice. Methods in molecular biology (Clifton, NJ). 2015;1332:161-76.

126. Guan M, Jin J, Su B, Liu WW, Lu Y. Tissue factor expression and angiogenesis in human glioma. Clin Biochem. 2002;35(4):321-5.

127. Khorana AA, Ahrendt SA, Ryan CK, Francis CW, Hruban RH, Hu YC, et al. Tissue factor expression, angiogenesis, and thrombosis in pancreatic cancer. Clin Cancer Res. 2007;13(10):2870-5

128. Abdulkadir SA, Carvalhal GF, Kaleem Z, Kisiel W, Humphrey PA, Catalona WJ, et al. Tissue factor expression and angiogenesis in human prostate carcinoma. Human pathology. 2000;31(4):443-7.

129. Nakasaki T, Wada H, Shigemori C, Miki C, Gabazza EC, Nobori T, et al. Expression of tissue factor and vascular endothelial growth factor is associated with angiogenesis in colorectal cancer. Am J Hematol. 2002; 69(4):247-54

130. Koomagi R, Volm M. Tissue-factor expression in human non-small-cell lung carcinoma measured by immunohistochemistry: correlation between tissue factor and angiogenesis. International journal of cancer. 1998;79(1):19-22.
131. Bluff JE, Menakuru SR, Cross SS, Higham SE, Balasubramanian SP, Brown NJ, et al. Angiogenesis is associated with the onset of hyperplasia in human ductal breast disease. British journal of cancer. 2009;101(4):666-72.

132. Yin YJ, Salah Z, Maoz M, Even Ram SC, Ochayon S, Neufeld G, et al. Oncogenic transformation induces tumor angiogenesis: a role for PAR1 activation. FASEB journal : official publication of the Federation of American Societies for Experimental Biology. 2003;17(2):163-74.

133. Nierodzik ML, Karpatkin S. Thrombin induces tumor growth, metastasis, and angiogenesis: evidence for a thrombin-regulated dormant tumor phenotype. Cancer cell. 2006;10(5):355-62.

134. Connolly AJ, Suh DY, Hunt TK, Coughlin SR. Mice lacking the thrombin receptor, PAR1, have normal skin wound healing. The American journal of pathology. 1997;151(5):1199-204.

135. Uusitalo-Jarvinen H, Kurokawa T, Mueller BM, Andrade-Gordon P, Friedlander M, Ruf W. Role of protease activated receptor 1 and 2 signaling in hypoxia-induced angiogenesis. Arteriosclerosis, thrombosis, and vascular biology. 2007;27(6):1456-62.

136. Versteeg HH, Schaffner F, Kerver M, Ellies LG, Andrade-Gordon P, Mueller BM, et al. Protease-activated receptor (PAR) 2, but not PAR1, signaling promotes the development of mammary adenocarcinoma in polyoma middle T mice. Cancer research. 2008;68(17):7219-27.

137. Signaevsky M, Hobbs J, Doll J, Liu N, Soff GA. Role of alternatively spliced tissue factor in pancreatic cancer growth and angiogenesis. Seminars in thrombosis and hemostasis. 2008;34(2):161-9.

138. Wu M, Chen L, Xu T, Xu B, Jiang J, Wu C. Prognostic values of tissue factor and its alternatively splice transcripts in human gastric cancer tissues. Oncotarget. 2017:8(32):53137-45.

139. Rollin J, Regina S, Gruel Y. Tumor expression of alternatively spliced tissue factor is a prognostic marker in non-small cell lung cancer. J Thromb Haemost. 2010;8(3):607-10.

140. Leppert $\mathrm{U}$, Eisenreich $\mathrm{A}$. The role of tissue factor isoforms in cancer biology. International journal of cancer. 2015;137(3):497-503.

141. Hu L, Xia L, Zhou H, Wu B, Mu Y, Wu Y, et al. TF/FVIla/PAR2 promotes cell proliferation and migration via PKCalpha and ERK-dependent c-Jun/AP-1 pathway in colon cancer cell line SW620. Tumour Biol. 2013;34(5):2573-81.

142. Wu B, Zhou H, Hu L, Mu Y, Wu Y. Involvement of PKCalpha activation in TF/ VIla/PAR2-induced proliferation, migration, and survival of colon cancer cell SW620. Tumour Biol. 2013;34(2):837-46.

143. Kocaturk B, Van den Berg YW, Tieken C, Mieog JS, de Kruijf EM, Engels CC, et al. Alternatively spliced tissue factor promotes breast cancer growth in a beta1 integrin-dependent manner. Proc Natl Acad Sci U S A. 2013;110(28): $11517-22$.

144. Versteeg HH, Spek CA, Slofstra SH, Diks SH, Richel DJ, Peppelenbosch MP. FVIla:TF induces cell survival via G12/G13-dependent Jak/STAT activation and BCIXL production. Circulation research. 2004;94(8):1032-40.

145. Sorensen BB, Rao LV, Tornehave D, Gammeltoft S, Petersen LC. Antiapoptotic effect of coagulation factor Vlla. Blood. 2003;102(5):1708-15.

146. Versteeg HH, Spek CA, Richel DJ, Peppelenbosch MP. Coagulation factors VIlla and Xa inhibit apoptosis and anoikis. Oncogene. 2004;23(2):410-7.

147. Aberg M, Wickstrom M, Siegbahn A. Simvastatin induces apoptosis in human breast cancer cells in a NFkappaB-dependent manner and abolishes the anti-apoptotic signaling of TF/FVIla and TF/FVIla/FXa. Thrombosis research. 2008;122(2):191-202.

148. Aberg M, Johnell M, Wickstrom M, Siegbahn A. Tissue factor/FVlla prevents the extrinsic pathway of apoptosis by regulation of the tumor suppressor Death-Associated Protein Kinase 1 (DAPK1). Thrombosis research. 2011; 127(2):141-148.

149. Horbinski C, Mojesky C, Kyprianou N. Live free or die: tales of homeless (cells) in cancer. The American journal of pathology. 2010;177(3):1044-52.

150. Yu Z, Pestell TG, Lisanti MP, Pestell RG. Cancer stem cells. Int J Biochem Cell Biol. 2012;44(12):2144-51.

151. Milsom C, Magnus N, Meehan B, Al-Nedawi K, Garnier D, Rak J. Tissue factor and cancer stem cells: is there a linkage? Arteriosclerosis, thrombosis, and vascular biology. 2009;29(12):2005-14.

152. Garnier D, Milsom C, Magnus N, Meehan B, Weitz J, Yu J, et al. Role of the tissue factor pathway in the biology of tumor initiating cells. Thrombosis research. 2010;125(Suppl 2):S44-50.

153. Milsom C, Anderson GM, Weitz Jl, Rak J. Elevated tissue factor procoagulant activity in CD133-positive cancer cells. J Thromb Haemost. 2007;5(12):2550-2.

154. Long $H$, Xie $R$, Xiang $T$, Zhao $Z$, Lin $S$, Liang $Z$, et al. Autocrine CCL5 signaling promotes invasion and migration of CD133+ ovarian cancer stem- 
like cells via NF-kappaB-mediated MMP-9 upregulation. Stem cells (Dayton, Ohio). 2012;30(10):2309-19.

155. Hu Z, Xu J, Cheng J, McMichael E, Yu L, Carson WE 3rd. Targeting tissue factor as a novel therapeutic oncotarget for eradication of cancer stem cells isolated from tumor cell lines, tumor xenografts and patients of breast, lung and ovarian cancer. Oncotarget. 2017;8(1):1481-94.

156. Shaker H, Harrison H, Clarke R. Landberg G. Versteeg HH, et al. Tissue factor promotes breast cancer stem cell activity in vitro. Oncotarget: Bundred NJ; 2016.

157. Magnus N, Garnier D, Meehan B, McGraw S, Lee TH, Caron M, et al. Tissue factor expression provokes escape from tumor dormancy and leads to genomic alterations. Proc Natl Acad Sci U S A. 2014;111(9):3544-9.

158. Schaffner F, Yokota N, Carneiro-Lobo T, Kitano M, Schaffer M, Anderson GM, et al. Endothelial protein $\mathrm{C}$ receptor function in murine and human breast cancer development. PloS one. 2013;8(4):e61071.

159. Poon RT, Lau CP, Ho JW, Yu WC, Fan ST, Wong J. Tissue factor expression correlates with tumor angiogenesis and invasiveness in human hepatocellular carcinoma. Clin Cancer Res. 2003;9(14):5339-45.

160. Vrana JA, Stang MT, Grande JP, Getz MJ. Expression of tissue factor in tumor stroma correlates with progression to invasive human breast cancer: paracrine regulation by carcinoma cell-derived members of the transforming growth factor beta family. Cancer research. 1996;56(21):5063-70.

161. Kakkar AK, Lemoine NR, Scully MF, Tebbutt S, Williamson RC. Tissue factor expression correlates with histological grade in human pancreatic cancer. $\mathrm{Br}$ J Surg. 1995;82(8):1101-4.

162. Sawada M, Miyake S, Ohdama S, Matsubara O, Masuda S, Yakumaru K, et al. Expression of tissue factor in non-small-cell lung cancers and its relationship to metastasis. British journal of cancer. 1999;79(3-4):472-7.

163. Mueller BM, Reisfeld RA, Edgington TS, Ruf W. Expression of tissue factor by melanoma cells promotes efficient hematogenous metastasis. Proc Natl Acad Sci U S A. 1992;89(24):11832-6.

164. Morrow JJ, Bayles I, Funnell APW, Miller TE, Saiakhova A, Lizardo MM, et al. Corrigendum: positively selected enhancer elements endow osteosarcoma cells with metastatic competence. Nature medicine. 2018;24(4):525.

165. Ngo CV, Picha K, McCabe F, Millar H, Tawadros R, Tam SH, et al. CNTO 859, a humanized anti-tissue factor monoclonal antibody, is a potent inhibitor of breast cancer metastasis and tumor growth in xenograft models. International journal of cancer. 2007;120(6):1261-7.

166. Bromberg ME, Konigsberg WH, Madison JF, Pawashe A, Garen A. Tissue factor promotes melanoma metastasis by a pathway independent of blood coagulation. Proc Natl Acad Sci U S A. 1995;92(18):8205-9.

167. Bromberg ME, Sundaram R, Homer RJ, Garen A, Konigsberg WH. Role of tissue factor in metastasis: functions of the cytoplasmic and extracellular domains of the molecule. Thrombosis and haemostasis. 1999;82(1):88-92.

168. Ge L, Ly Y, Hollenberg M, DeFea K. A beta-arrestin-dependent scaffold is associated with prolonged MAPK activation in pseudopodia during protease-activated receptor-2-induced chemotaxis. The Journal of biological chemistry. 2003;278(36):34418-26.

169. Nag JK, Kancharla A, Maoz M, Turm H, Agranovich D, Gupta CL, et al. Lowdensity lipoprotein receptor-related protein 6 is a novel coreceptor of protease-activated receptor-2 in the dynamics of cancer-associated betacatenin stabilization. Oncotarget. 2017;8(24):38650-67.

170. Unruh D, Unlu B, Lewis CS, Qi X, Chu Z, Sturm R, et al. Antibody-based targeting of alternatively spliced tissue factor: a new approach to impede the primary growth and spread of pancreatic ductal adenocarcinoma. Oncotarget. 2016;7(18):25264-75.

171. Das K, Prasad R, Roy S, Mukherjee A, Sen P. The protease activated receptor2 promotes Rab5a mediated generation of pro-metastatic microvesicles. Scientific reports. 2018;8(1):7357.

172. Ender F, Freund A, Quecke T, Steidel C, Zamzow P, von Bubnoff N, et al. Tissue factor activity on microvesicles from cancer patients. Journal of cancer research and clinical oncology. 2020;146(2):467-75.

173. Che SPY, Park JY, Stokol T. Tissue factor-expressing tumor-derived extracellular vesicles activate quiescent endothelial cells via proteaseactivated receptor-1. Front Oncol. 2017;7:261.

174. Benelhaj NE, Maraveyas A, Featherby S, Collier MEW, Johnson MJ, Ettelaie C. Alteration in endothelial permeability occurs in response to the activation of PAR2 by factor Xa but not directly by the TF-factor Vlla complex. Thrombosis research. 2019;175:13-20.

175. Gil-Bernabé AM, Ferjancic S, Tlalka M, Zhao L, Allen PD, Im JH, et al. Recruitment of monocytes/macrophages by tissue factor-mediated coagulation is essential for metastatic cell survival and premetastatic niche establishment in mice. Blood. 2012;119(13):3164-75.

176. Huang M, Syed R, Stura EA, Stone MJ, Stefanko RS, Ruf W, et al. The mechanism of an inhibitory antibody on TF-initiated blood coagulation revealed by the crystal structures of human tissue factor, Fab 5G9 and TF.G9 complex. J Mol Biol. 1998;275(5):873-94.

177. Palumbo JS, Talmage KE, Massari JV, La Jeunesse CM, Flick MJ, Kombrinck KW, et al. Tumor cell-associated tissue factor and circulating hemostatic factors cooperate to increase metastatic potential through natural killer celldependent and-independent mechanisms. Blood. 2007;110(1):133-41.

178. Hembrough TA, Swartz GM, Papathanassiu A, Vlasuk GP, Rote WE, Green SJ, et al. Tissue factor/factor VIla inhibitors block angiogenesis and tumor growth through a nonhemostatic mechanism. Cancer research. 2003;63(11):2997-3000

179. Zhao J, Aguilar G, Palencia S, Newton E, Abo A. rNAPc2 inhibits colorectal cancer in mice through tissue factor. Clin Cancer Res. 2009;15(1):208-16.

180. Moons AH, Peters RJ, Bijsterveld NR, Piek JJ, Prins MH, Vlasuk GP, et al. Recombinant nematode anticoagulant protein c2, an inhibitor of the tissue factor/factor Vlla complex, in patients undergoing elective coronary angioplasty. Journal of the American College of Cardiology. 2003;41(12):2147-53.

181. D'Asti E, Anderson GM, Rak J. Inhibition of tissue factor signaling in breast tumour xenografts induces widespread changes in the microRNA expression profile. Biochemical and biophysical research communications. 2017:494(3-4):700-5.

182. Barry GD, Suen JY, Le GT, Cotterell A, Reid RC, Fairlie DP. Novel agonists and antagonists for human protease activated receptor 2. Journal of medicinal chemistry. 2010;53(20):7428-40.

183. Jiang Y, Yau MK, Lim J, Wu KC, Xu W, Suen JY, et al. A potent antagonist of protease-activated receptor 2 that inhibits multiple signaling functions in human cancer cells. The Journal of pharmacology and experimental therapeutics. 2018;364(2):246-57.

184. Lohman RJ, Cotterell AJ, Barry GD, Liu L, Suen JY, Vesey DA, et al. An antagonist of human protease activated receptor-2 attenuates PAR2 signaling, macrophage activation, mast cell degranulation, and collageninduced arthritis in rats. FASEB journal : official publication of the Federation of American Societies for Experimental Biology. 2012;26(7):2877-87.

185. Hamilton JR, Trejo J. Challenges and opportunities in protease-activated receptor drug development. Annu Rev Pharmacol Toxicol. 2017;57:349-73.

186. Liu X, Yu J, Song S, Yue X, Li Q. Protease-activated receptor-1 (PAR-1): a promising molecular target for cancer. Oncotarget. 2017;8(63):107334-45.

187. Covic L, Kuliopulos A. Protease-activated receptor 1 as therapeutic target in breast, lung, and ovarian cancer: pepducin approach. International journal of molecular sciences. 2018;19(8).

188. Cisowski J, O'Callaghan K, Kuliopulos A, Yang J, Nguyen N, Deng Q, et al. Targeting protease-activated receptor-1 with cell-penetrating pepducins in lung cancer. The American journal of pathology. 2011;179(1):513-23.

189. Ramachandran R, Noorbakhsh F, Defea K, Hollenberg MD. Targeting proteinase-activated receptors: therapeutic potential and challenges. Nature reviews Drug discovery. 2012;11(1):69-86.

190. Bobek V, Kovarik J. Antitumor and antimetastatic effect of warfarin and heparins. Biomed Pharmacother. 2004;58(4):213-9.

191. Schulman S, Lindmarker P. Incidence of cancer after prophylaxis with warfarin against recurrent venous thromboembolism. Duration of Anticoagulation Trial. N Engl J Med. 2000;342(26):1953-8.

192. Pengo V, Noventa F, Denas G, Pengo MF, Gallo U, Grion AM, et al. Longterm use of vitamin $\mathrm{K}$ antagonists and incidence of cancer: a populationbased study. Blood. 2011;117(5):1707-9.

193. Kirane A, Ludwig KF, Sorrelle N, Haaland G, Sandal T, Ranaweera R, et al. Warfarin blocks Gas6-mediated Axl activation required for pancreatic cancer epithelial plasticity and metastasis. Cancer research. 2015;75(18):3699-705.

194. Maqsood A, Hisada Y, Garratt KB, Homeister J, Mackman N. Rivaroxaban does not affect growth of human pancreatic tumors in mice. J Thromb Haemost. 2019;17(12):2169-73.

195. Graf C, Wilgenbus P, Pagel S, Pott J, Marini F, Reyda S, et al. Myeloid cellsynthesized coagulation factor $X$ dampens antitumor immunity. Sci Immunol. 2019;4(39).

196. Prescott J, Thiemann P, Loury D. PCl-27483, a small molecule inhibitor of Factor VIla, inhibits growth of BXPC3 pancreatic adenocarcinoma xenograft tumors. Cancer research. 2008:68(9 Supplement):5669-.

197. Ramanathan RK, Thomas GW, Khorana AA, Shah S, Zhou C, Wong S, et al. A phase 2 study of PCI-27483, a Factor VIla inhibitor in combination with gemcitabine for advanced pancreatic cancer. Oncology. 2019;96(4):217-22. 
198. Breij EC, de Goeij BE, Verploegen S, Schuurhuis DH, Amirkhosravi A, Francis $J$, et al. An antibody-drug conjugate that targets tissue factor exhibits potent therapeutic activity against a broad range of solid tumors. Cancer research. 2014:74(4):1214-26.

199. Zhang X, Li Q, Zhao H, Ma L, Meng T, Qian J, et al. Pathological expression of tissue factor confers promising antitumor response to a novel therapeutic antibody $\mathrm{SC} 1$ in triple negative breast cancer and pancreatic adenocarcinoma. Oncotarget. 2017;8(35):59086-102.

200. de Goeij BE, Satijn D, Freitag CM, Wubbolts R, Bleeker WK, Khasanov A, et al. High turnover of tissue factor enables efficient intracellular delivery of antibody-drug conjugates. Mol Cancer Ther. 2015;14(5):1130-40.

201. Hu Z, Sun Y, Garen A. Targeting tumor vasculature endothelial cells and tumor cells for immunotherapy of human melanoma in a mouse xenograft model. Proc Natl Acad Sci U S A. 1999;96(14):8161-6.

202. Hu Z, Garen A. Targeting tissue factor on tumor vascular endothelial cells and tumor cells for immunotherapy in mouse models of prostatic cancer. Proc Natl Acad Sci U S A. 2001;98(21):12180-5.

203. Cheng J, Xu J, Duanmu J, Zhou H, Booth CJ, Hu Z. Effective treatment of human lung cancer by targeting tissue factor with a factor VII-targeted photodynamic therapy. Curr Cancer Drug Targets. 2011;11(9):1069-81.

204. Hu Z, Li J. Natural killer cells are crucial for the efficacy of Icon (factor VII/ human lgG1 Fc) immunotherapy in human tongue cancer. BMC Immunol. 2010;11:49.

205. Hu Z, Garen A. Intratumoral injection of adenoviral vectors encoding tumortargeted immunoconjugates for cancer immunotherapy. Proc Natl Acad Sci U S A. 2000;97(16):9221-5.

206. Hu Z, Shen R, Campbell A, McMichael E, Yu L, Ramaswamy B, et al. Targeting tissue factor for immunotherapy of triple-negative breast cancer using a second-generation ICON. Cancer Immunol Res. 2018;6(6):671-84.

207. Subklewe M, von Bergwelt-Baildon M, Humpe A. Chimeric antigen receptor $T$ cells: a race to revolutionize cancer therapy. Transfus Med Hemother. 2019;46(1):15-24.

208. Miliotou AN, Papadopoulou LC. CAR T-cell therapy: a new era in cancer immunotherapy. Curr Pharm Biotechnol. 2018;19(1):5-18.

209. McHayleh W, Bedi P, Sehgal R, Solh M. Chimeric antigen receptor T-cells: the future is now. J Clin Med. 2019;8(2).

210. Zhang Q, Wang H, Li H, Xu J, Tian K, Yang J, et al. Chimeric antigen receptor-modified $T$ cells inhibit the growth and metastases of established tissue factor-positive tumors in NOG mice. Oncotarget. 2017;8(6):9488-99.

211. Lee SC, Abdel-Wahab O. Therapeutic targeting of splicing in cancer. Nature medicine. 2016;22(9):976-86.

\section{Publisher's Note}

Springer Nature remains neutral with regard to jurisdictional claims in published maps and institutional affiliations.

Ready to submit your research? Choose BMC and benefit from:

- fast, convenient online submission

- thorough peer review by experienced researchers in your field

- rapid publication on acceptance

- support for research data, including large and complex data types

- gold Open Access which fosters wider collaboration and increased citations

- maximum visibility for your research: over $100 \mathrm{M}$ website views per year

At $\mathrm{BMC}$, research is always in progress.

Learn more biomedcentral.com/submissions 